NEBOJŠA JOVANOVIĆ, urednik

Zavod za udžbenike

UDK 355.426(497.5)"1991"(093.3)

Beograd, Obilićev venac 5

356/358(497.5)"1991"(093.3)

\title{
POHOD 169. MOTORIZOVANE BRIGADE JNA U HRVATSKOJ 1991.
}

\author{
Sećanje učesnika
}

\begin{abstract}
APSTRAKT: Članak predstavlja osvrt savremenika na ratni put jedne od ratnih brigada JNA mobilisanih u zapadnoj Srbiji tokom rata u Hrvatskoj 1991. godine. Razmatran je ratni put brigade od mobilizacije u rejonu Loznice, preko marša i obuke u Bosni, do borbi oko Karlovca, u periodu septembar - oktobar 1991.
\end{abstract}

Ključne reči: Jugoslavija, JNA, Hrvatska, mobilizacija, 169. motorizovana brigada

Novosadski korpus Jugoslovenske narodne armije (JNA) predao je 20. septembra 1991. iz svog sastava 169. motorizovanu brigadu Banjalučkom korpusu pod neposrednu komandu, radi ostvarivanja strateških ciljeva na ratištu koje je već bilo otvoreno u Hrvatskoj - između JNA, Teritorijalne odbrane (TO) novoproglašene SAO Krajine, $s$ jedne strane i novoformiranih hrvatskih vojnih formacija: Zbora narodne garde (ZNG), Hrvatskog vijeća obrane (HVO) i MUP-a Hrvatske, s druge. Komandant Banjalučkog korpusa JNA bio je general-major Nikola Uzelac, a komandant 169. motorizovane brigade pukovnik Nikola Mladenović. Brigada je popunjena vojnicima, podoficirima i oficirima iz rezervnog sastava JNA sa prostora četiri opštine u zapadnoj Srbiji: Loznice, Krupnja, Malog Zvornika i Ljubovije. Ukupan broj (odazvanih na mobilizaciju) vojnika iznosio je 4.326 od 6.000 pozvanih. Aktivne vojne starešine bili su samo: komandant brigade (pukovnik Mladenović), načelnik štaba (potpukovnik Milan Jović), pomoćnik načelnika štaba (potpukovnik Stojan Stevanović) i načelnik operativnog odeljenja Komande brigade (major Dragan Jovanović). Sve ostale starešine i vojnici pripadali su rezervnom sastavu. Brigada je raspolagala sa četiri pešadijska bataljona, inženjerijskom četom, izviđačkom četom, dva haubička diviziona, jednim LPA (laka protivvazdušna artiljerija) divizionom, jednim mešovitim protivoklopnim divizionom, četom ABHO (antibiološko-hemijska odbrana), pozadinskom četom i prištapskim jedinicama. 
Okupljanje sastava 169 . motorizovane brigade za konačan pohod ${ }^{1} \mathrm{u} \mathrm{Hr}-$ vatsku počelo je 16. a završeno 18 . septembra na mestima ratnog rasporeda vojnih obveznika u selima oko Loznice, Krupnja, Malog Zvornika i Ljubovije. Komanda brigade bila je u vojnom garnizonu u Loznici („Klupci“), pa je cela jedinica neslužbeno nazivana Loznička brigada. Sutradan po okupljanju, 19. septembra, brigada je prebačena u Mačvu. Komanda i prištapske jedinice bile su razmeštene u Bogatiću (Poljoprivredno dobro „Ogled), a ostale jedinice u okolnim mačvanskim selima (Glušci, Klenje, Štitar, Noćaj, Crna Bara, Badovinci...). Precizan razlog, maršruta i cilj predstojećeg pohoda nisu bili još uvek poznati ni u Komandi brigade. Tek 20. septembra u popodnevnim satima, iz komande Novosadskog korpusa stigle su dve naredbe: prva, o predaji 169. motorizovane brigade Banjalučkom korpusu na raspolaganje za ratna dejstva u Hrvatskoj i druga, da brigada do 21. septembra (sutradan) u 12 časova zauzme Hrvatsku Kostajnicu i u njoj sačeka dalja naređenja.

Maršrutom preko severne Bosne (Bogatić, Tuzla, Doboj, Derventa, Banjaluka, Bosanski Novi, Bosanska Kostajnica, Hrvatska Kostajnica), koja je sačinjena u komandi same brigade, celokupna 169. brigada kretala se tokom noći 20/21. septembra i u podne (dogovorenog dana i sata, 21. septembra) ušla je u sablasno pustu Hrvatsku Kostajnicu, gde je nije dočekao niko od civilnih i vojnih vlasti, ni od stanovništva. Vojnici su preko mosta na Uni prelazili u Bosansku Kostajnicu, kupovali hranu, cigarete, pivo i druge potrepštine jer je u tom gradu sve bilo otvoreno i funkcionisalo kao u mirnodopsko vreme.

Saznalo se, u razgovoru sa meštanima, da su se borbe u Hrvatskoj Kostajnici vodile još u junu i da su tada vojnici TO (SAO Krajina) naneli odlučujuće poraze snagama hrvatskog MUP-a, ZNG i HVO. Od tada su i meštani Hrvatske Kostajnice napustili grad: Hrvati su se povukli ka severu, na teritorije u Baniji koje su još uvek kontrolisale snage novoformiranih hrvatskih vojski a srpsko stanovništvo povuklo se ka zapadu (Banija, Kordun) ili jugu (severozapadna Bosna), od kojih se muško, vojno sposobno stanovništvo priključilo TO Krajine. Dokaze o vekovnom saživotu u istom gradu pružali su samo prelepi stari hramovi Srpske pravoslavne crkve i Rimokatoličke crkve. Predveče istog dana (21. septembra), brigada je dobila naređenje da se vrati u Banjaluku i rasporedi na vojnom poligonu Zalužani, severno od grada, pored regionalnog puta BanjalukaGradiška.

Na poligonu Zalužani bilo je tih dana više brigada Jugoslovenske narodne armije. Svakoga dana po nekoliko jedinica odlazilo je na sever, u pravcu Gradiške, Okučana i Lipika, odakle su se, čak do Banjaluke, čuli odjeci artiljerijske i raketne vatre u borbama kojima se krčio vojni koridor Okučani-Daruvar, u Hrvatskoj (zapadna Slavonija). Taj koridor trebalo je da posluži brigadama (pre svih tenkovskim) koje su nadirale iz pravca istočne Slavonije prema Zagrebu, kao

${ }^{1}$ Brigada je pre toga dva puta okupljana: od 30. juna do 3. jula i od 8. jula do 16. avgusta, ali nije pokretana sa početnih položaja. 
krajnjem cilju pohoda. U sklopu složene vojne operacije opkoljavanja (stavljanja u tzv. prsten) i zauzimanja Zagreba, 169. brigada je upućena 28. septembra sa poligona Zalužani - preko Bosanskog Novog i Dvora na Uni - u selo Dragotina, na Baniji, južno od Gline. U isto vreme TO Banije je zauzimala sela Maja, Gornji Viduševac i Donji Viduševac oko same Gline, kako bi 169. brigadi JNA olakšala ulazak u Glinu i dalje nadiranje prema Zagrebu.

Rano ujutru, 1. oktobra 1991. Komanda 169. brigade, razmeštena u Dragotini, dobija naređenje da zauzme Glinu, a odatle - umesto na sever, kako je to bilo očekivano - da krene ka severozapadu i preko Korduna (Topusko, Vrgin Most, Vojnić, Turanj...), zauzme najpre Karlovac i potom zaokrene i produži na severoistok, prema Zagrebu, gde bi se privremeno - dok se ne stegne ceo vojni prsten - zaustavila u Jastrebarskom. Istoga dana, u 14,30 časova brigada je preko Vojnića, Živković-kose i Mađerčića brda stigla u rejon tzv. očekivanih položaja, južno od Karlovca, razmeštajući se za napad na grad u prostoru između reka Korane na zapadu i Kupe na severoistoku. Korana se, inače, u samom Karlovcu uliva u Kupu. U Karlovcu je u tom trenutku bilo 49 vojnih objekata i kasarni koje su pripadnici novoformiranih hrvatskih vojski stavili pod blokadu, zajedno sa vojnicima, starešinama i vojnom tehnikom u vlasništvu JNA. Tražena je predaja svih kasarni, vojnika i celokupne tehnike, pod pretnjom ubijanja svih zarobljenih vojnika i pripadnika rezervnog sastava. Staviše, 21. septembra, na Koranskom mostu, u centru grada, izvršen je pokolj svih 13 vojnika-rezervista koji su se vojnim kamionom kretali iz kasarne u Mekušju (predgrađu Karlovca) u kasarnu „Stjepan Milašinović-Šiljo“ u centru Karlovca. ${ }^{2}$

Celokupna 169. brigada, njena Komanda i prištapske jedinice razmestile su se 3. oktobra na borbene položaje oko Karlovca. Sama komanda i prištapske jedinice smestile su se u selu Pogledić, 8 kilometara južno od grada. ${ }^{3}$ Istog dana proglašena je opšta mobilizacija na teritoriji opštine Vojnić. U 10 sati pre podne, 5. oktobra, uz pomoć pripadnika TO Vojnić, otpočeo je napad na Karlovac s ciljem deblokiranja i oslobađanja svih kasarni, objekata i ljudstva JNA u samom gradu. Treći pešadijski bataljon na levom, zapadnom krilu, napredovao je niz desnu obalu Korane, od Cerovca Tušilovačkog, kroz Jelaše do sela Turanj, koje je praktično bilo predgrađe Karlovca. Drugi bataljon, u sredini, zauzimao je sela Popović Brdo i Kamensko a prvi bataljon, na desnom krilu, prolazio je kroz sela Skakavac, Brežane, Lipje i Ribare, prilazeći gradu. Četvrti, rezervni pešadijski bataljon, ušao je u sela Vukmanić i Knežgoricu, kako bi se u tom rejonu locirala jedna topovska baterija. ${ }^{4}$ Hrvatska vojska odmah je odgovorila haubičkom i raketnom vatrom iz sela Rečica, severno od Kupe, i iz prigradskog naselja Duga resa, na ušću Mrežnice u Koranu, po svim položajima 169. brigade. Do kraja dana,

${ }^{2}$ Politika, 22. septembar 1991, 1-2; Nebojša Jovanović, Dnevnik sa rezervistima, Historia vulgata, Beograd 1998, 135-170.

${ }^{3}$ N. Jovanović, Dnevnik sa rezervistima, 167.

${ }^{4}$ Isto, $174-175$. 
razmenom artiljerijske i raketne vatre sa obe strane, hrvatske haubičke i raketne baterije su sa više preciznih hitaca bile potpuno uništene i opasnost s tih strana je nakratko neutralisana. ${ }^{5}$ Pomoć u neutralisanju opasnosti pružila je i avijacija JNA koja je nadletala sa aerodroma iz Bihaća.

U samom Karlovcu zavladala je panika među preostalim civilnim stanovništvom. Veliki deo srpskih civila ranije je napustio grad i sklonio se na Kordun. ${ }^{6}$ Preostalo stanovništvo je tog dana u ogromnom broju počelo da napušta Karlovac i da se u kolonama, automobilima, autobusima, peške, kako je ko mogao, povlači prema Zagrebu. Udarne vesti HRT-a te večeri bile su vezane za grad na Kupi: saopšteno je da su pogođene autobuska stanica, zgrada Auto-Hrvatske, sud i tržnica, a da su u avionskim napadima tučena naselja Duga resa, Švarča, Rečica i Kobilić, najposle da je u gradu veliki broj civilnih žrtava, od kojih mnoge još nisu ni pronađene u zgarištima. ${ }^{7}$

Istog dana deblokirana je kasarna u Kamenskom (južno od Karlovca, jedna od najvećih u gradu) i započelo je izvlačenje vojnika i tehnike na teritoriju Korduna. Izveštaji izviđača 169. brigade govorili su da je zbog artiljerijske vatre i hrvatske vojske i JNA najviše stradalo naselje Jelaši, gde gotovo nijedna kuća nije ostala čitava. U tom selu, inače, dogodio se najžešći pešadijski sukob između hrvatskih vojnika i 3. bataljona 169. brigade. Po ovladavanju selom, preživelim meštanima (civilima) pripadnici 169. brigade omogućili su bezbedan prelazak preko Korane, na zapad, u hrvatska sela. ${ }^{8}$

Do 7. oktobra brigada je ovladala celokupnim prostorom između reka Korane i Kupe i praktično je, u dubokom džepu, držala ceo južni ulaz u grad. Dva dana kasnije (9. oktobar), ceo Karlovac je bio pod komandom 169. motorizovane brigade JNA, sve kasarne i vojni objekti bili su deblokirani, a vojnici i starešine sa celokupnom tehnikom su delom upućivani na izvlačenje iz grada prema jugu a delom su uključivani u sadejstvo sa 169. brigadom, na putu ka Jastrebarskom i Zagrebu. Komandant Karlovca, pukovnik Svetozar Marjanović, ${ }^{9}$ smestio je svoju komandu blizu komande 169. brigade, u selu Utinji (Kordun), a brojnu tehniku rasporedio je po desnoj obali Kupe, držeći most na toj reci kod sela Skakavac, kuda je nameravao da se prebaci i da preko Pisarevine stigne do Zagreba. U operativnom odeljenju Komande 169. motorizovane brigade već su bile

${ }^{5}$ Isto, $180-181$.

${ }^{6}$ U Karlovcu je 1991. godine broj stanovnika po nacionalnoj opredeljenosti bio gotovo ujednačen: 50\% činili su Hrvati, 45\% Srbi, 4\% Jugosloveni, 1\% ostali; mnogi Srbi su pod prisilom još od prethodne, 1990. godine, bili primorani da napuste grad (otkaz s posla, oduzimanje stana, različite pretnje i dr.); N. Jovanović, $n$. $d$., 172-173.

${ }^{7}$ Dnevnik RTS je tog dana u 19,30 časova saopštio da je u Karlovcu već prvog dana napada JNA „ubijeno više od petsto ustaša“; Isto, 186-187.

${ }^{8}$ Isto, 210-211.

9 Svetozar Marjanović (1950), danas general-armije u penziji; šroj javnosti ostao je upamćen kao jedan od potpisnika Kumanovskog sporazuma, 9. juna 1999, između Vojske Jugoslavije i NATO. 
kodirane sve topografske sekcije i do detalja razrađen plan (Nišava) daljeg napredovanja ka Jastrebarskom. Praktično, jači otpor se više nije ni očekivao do samog prilaza Zagrebu.

Međutim, 10. oktobra brigada je iz korpusa dobila naređenje da se povuče iz grada na prostor južnije od ušća Korane u Kupu. Sutradan je stiglo naređenje da se ponovo uđe u Karlovac, na položaje koji su držani 9. i 10. oktobra. Konačno, 12. oktobra uveče - umesto očekivanog naređenja da se krene ka Jastrebarskom - stigla je potpuno neočekivana naredba da 169. brigada napusti sve položaje, preda ih Teritorijalnoj odbrani i pod hitno se vrati u Srbiju.

$\mathrm{U}$ prvom ratnom pohodu 169 . motorizovane brigade $\mathrm{JNA}^{10}$ poginula su četiri vojnika, jedan vojnik je nestao (u Karlovcu), a 36 vojnika je teže i lakše ranjeno.

${ }^{10}$ Brigada je u novembru poslata u istočnu Slavoniju (Šodolovci), gde je ostala do maja 1992. 
Nebojša Jovanović

\section{THE 169TH MOTORISED BRIGADE DURING THE WAR IN CROATIA 1991}

\section{Summary}

The article provides detailed account of the engagment of the 169th Motorised Brigade of the Yugoslav People's Army during the wat in Croatia 1991. Author, who personnaly participated in a ranks of the brigade, reviels the unit's operational history. From the proces of the mobilisation in Western Serbia in mid-September 1991, over the trainning and movement to the first line in vicinity of Karlovac, Croatia where brigade was engeged in combat. 